\title{
DETEKSI BAKTERI PENYEBAB PENYAKIT TYPHUS PADA MANUSIA DENGAN POL YMERASE CHAIN REACTION
}

\author{
Muktiningsih Nurjayadi $^{1 *}$, Fera Kurnia Dewi ${ }^{1}$, Dahlia ${ }^{2}$.S, Restu.N.S ${ }^{1}$, Fitri.W ${ }^{1}$. \\ ${ }^{1}$ Jurusan Kimia, Fakultas Matematika dan Ilmu Pengetahuan Alam,Universitas Negeri Jakarta, Rawamangun 13220, \\ Jakarta \\ ${ }^{2}$ Jurusan Biologi, Fakultas Matematika dan Ilmu Pengetahuan Alam,Universitas Negeri Jakarta, Rawamangun \\ 13220, Jakarta
}

*Corresponding author: mutinurjayadi@yahoo.com

\begin{abstract}
Abstrak
Salmonella typhi merupakan bakteri penyebab penyakit tifus pada manusia. Di Indonesia, angka morbiditas penderita penyakit typhus cenderung meningkat, sehingga diperlukan suatu alternatif untuk penanganan atau pencegahan penyakit tersebut. Sampai saat ini metode deteksi S. typhi yang banyak digunakan adalah uji serologi. Kelemahan metode ini adalah sering menghasilkan deteksi yang kurang akurat dan tidak spesifik. Pada penelitian yang dilakukan sebelumnya, telah berhasil ditemukan gen fimbrial-C S. typhi pengkode protein yang berperan dalam penempelan $S$. typhi pada usus manusia, hasil ini dijadikan landasan untuk pengembangan metode deteksi menggunakan teknik PCR. Tujuan penelitian ini mengembangkan metode deteksi yang akurat dan spesifik untuk bakteri penyebab penyakit typhus pada manusia. Hasil penelitian menunjukkan bahwa telah berhasil dilakukan amplifikasi gen fimbrial-C S. typhi menggunakan pasangan primer hasil perancangan yaitu FW-INT 2- REV-1A NEW. Keberhasilan tersebut ditunjukkan dengan diperolehnya pita DNA berukuran 0.2 kilo basa (kb) sesuai dengan ukuran pita DNA yang diharapkan dengan menggunakan template DNA genom bakteri $S$. typhi. Uji sensitivitas dan spesifisitas terhadap primer hasil rancangan sedang di kaji lebih lanjut untuk memperoleh reprodusibiltas hasil pengujian. Berdasarkan hasil yang diperoleh dapat disimpulkan bahwa telah berhasil dilakukan pengembangan metode deteksi $S$. typhi menggunakan pasangan primer fimbrial-C $S$. typhi. Pengkajian pengembangan metode deteksi yang dihasilkan ini diharapkan dapat lebih baik dibanding beberapa metode deteksi yang sudah ada.
\end{abstract}

Kata Kunci: Metode Deteksi Bakteri typhus, fim-C S. typhi, PCR

\begin{abstract}
Salmonella typhi is bacteria that cause typhoid disease in humans. In Indonesia, the morbidity number of typhoid disease tends to be increase. Thus, it has been requiring the alternative for handling or preventing that disease. Recently, the detection method commonly uses for S. typhi detection is Serological test. The weakness of this method is often producing less accurate and not specific detection. The previous research was successfully discovered S. typhi gene that codes protein which is contributed at adherents or colonization those bacteria in epithelial human cell. That result was base to develop detection on $S$. typhi method by Polymerase chain reaction (PCR). The aim of this research is developing a specific and accurate detection method for $S$. typhi bacteria by PCR. The research result is performed successfully to amplify the fimbrial-C S. typhi gene using pairs of primer FW-INT 2-REV-1A $N E W$ which was designed and synthesized in previous step. That success showed by the finding of the DNA fragment of 0.2 kilobase ( $\mathrm{kb}$ ) proffers to size of DNA fragment which is hopefully in using S. typhi genome as a template. Specificity and sensitivity test for those primers are still conducting to reproducibility results. Base on the results can be concluded that the research have successfully conducted in developing S. typhi detection method using pairs of S. typhi fimbrial-C primer. Hopefully, the studied of developing detection methods was conducted better compare with former detection methods.
\end{abstract}

Keywords: S. typhi detection method, fim-C S. typhi gene, PCR

\section{Pendahuluan}

Salmonella typhi merupakan bakteri penyebab penyakit tifus pada manusia. Penyakit ini merupakan penyakit infeksi usus yang disebabkan masuknya $S$. typhi ke dalam tubuh melalui makanan dan minuman yang terkontaminasi bakteri tersebut dalam jumlah tertentu. Epidemiologi penyakit tifus menunjukkan bahwa penyakit tersebut tersebar hampir diseluruh dunia, dan merupakan penyakit endemik yang sering 
dijumpai pada negara berkembang [Bernard, 1997]. Di Indonesia, angka morbiditas meningkat [Sumaryati dan Simanjuntak, 1997]. Melihat meningkatnya angka morbiditas tersebut maka diperlukan suatu alternatif untuk penanganan atau pencegahan penyakit typhus.

Gambaran klinis penyakit typhus atau demam tifoid seringkali tidak spesifik terutama pada anak sehingga dalam penegakan diagnosis diperlukan konfirmasi pemeriksaan laboratorium. Pemeriksaan penunjang ini meliputi pemeriksaan darah tepi, isolasi/biakan kuman, uji serologis dan identifikasi secara molekuler. Beberapa faktor penyebab demam tifoid masih terus menjadi masalah kesehatan penting di Indonesia meliputi pula keterlambatan penentuan diagnosis secara pasti. Penentuan diagnosis demam tifoid saat ini dilakukan secara klinis dan melalui pemeriksaan laboratorium. Diagnosis demam tifoid secara klinis seringkali tidak tepat karena tidak ditemukannya gejala klinis spesifik atau didapatkan gejala yang sama pada beberapa penyakit lain pada anak, terutama pada minggu pertama sakit. Hal ini menunjukkan perlunya pemeriksaan penunjang laboratorium untuk konfirmasi penegakan atau penentuan diagnosis demam tifoid.

Metode deteksi yang dipakai saat ini umumnya adalah metode serologi. Metode pemeriksaan serologis imunologis ini dikatakan mempunyai nilai penting dalam proses diagnostik demam tifoid. Akan tetapi masih didapatkan adanya variasi yang luas dalam sensitivitas dan spesifisitas pada deteksi antigen spesifik $S$. typhi oleh karena tergantung pada jenis antigen, jenis spesimen yang diperiksa, teknik yang dipakai untuk melacak antigen tersebut, jenis antibodi yang digunakan dalam uji (poliklonal atau monoklonal) dan waktu pengambilan spesimen (stadium dini atau lanjut dalam perjalanan penyakit).

Penelitian sebelumnya telah berhasil menemukan dan mengungkap fungsi protein fimbrial-C Salmonella typhi melalui pendekatan proteomik. Protein fim-C tersebut berfungsi sebagai alat untuk melekatkan diri penderita penyakit tersebut cenderung

pada usus manusia dan terletak pada bagian permukaan. Berdasarkan keberadaannya tersebut maka protein ini sangat potensial dijadikan target dalam merancang alat deteksi pada tingkat genomik dengan metode Polymerase Chain Reaction. Metode deteksi ini diharapkan dapat bersifat spesifik, sensitif dan akurat untuk mendeteksi keberadaan $S$. typhi pada penderita penyakit typhus.

Hasil penelitian ini diharapkan dapat bermanfaat dalam: (1) Menghasilkan rancangan primer spesifik berdasarkan urutan gen fim-C S. typhi (2) Menghasilkan pasangan molekul primer gen fim-C $S$. typhi (3) Memberikan informasi tentang spesivisitas dan sensitivitas pasangan primer fim-C dalam mendeteksi S. typhi, (4). Memberikan informasi tentang pemanfaatan metode deteksi ini pada pasien typhus. (5) Sebagai landasan dalam penemuan metode deteksi, yang diharapkan lebih baik dari metode yang ada sebelumnya.

\section{Metodologi Penelitian}

\subsection{Perancangan dan sintesis Primer spesifik} fimbrial-C S. typhi

Primer spesifik yang digunakan pada penelitian ini adalah pengembangan dari disain primer yang telah dirancang pada penelitian sebelumnya. Pada tahap penelitian sebelumnya primer didisain langsung dari urutan gen fim-C $S$. typhi. Disain tersebut primer dilakukan dengan prosedur standar dengan bantuan sistem komputer dan memperhatikan parameter-parameter disain primer, diantaranya adalah (1) panjang primer sebanyak 20-30 nukleotida (2) memiliki persen GC diatas 50\% (3) memperhatikan arah 3' dan 5' dari primer baik untuk reverse maupun forward. Pada tahap disain primer dihasilkan 4 rancangan primer gen fim-C $S$. typhi. Sebanyak dua buah rancangan primer Forward (FW-1b dan FW-Int2) dan 2 buah rancangan primer Reverse (Rev-1a New dan Rev-Int1 New). Panjang fragmen hasil amplifikasi FW-1b dan Rev-1a New 783 pasang basa (pb), Panjang fragmen hasil amplifikasi FW-1b dengan Rev-Int1 adalah $455 \mathrm{pb}$, dan panjang fragmen hasil amplifikasi 
primer Fw-Int2 dengan Rev-1a adalah 193 pb. Sintesis primer dilakukan oleh Company Eurofins MWG GmbH [MWG GmbH, 2008] yang berlokasi di Jerman dan difasiltasi oleh Prof.Dr.rer.nat Sentot Santoso dari Lab Immunologi Justus Liebieg Universitat German.

\subsection{Penelusuran biakan bakteri uji pada beberapa lab mikrobiologi}

Biakan bakteri uji yang digunakan dalam penelitian ini diperoleh dari beberapa laboratorium baik di Indonesia maupun di Jerman. Bakteri Salmonella typhimurium LT2 ATCC diperoleh dari Vaccine Group Laboratory GBF (German Biotechnology Forshung)-Brauschweig Germany. Bakteri Klebsiella pneumonia, Bakteri Salmonella typhi, Bakteri Enterobacter aerogenes, Bakteri Vibrio cholera, Escheria coli, dan Pseudomonas aeruginosa, diperoleh dari Laboratorium Mikrobiologi Universitas Indonesia.

\subsection{Penumbuhan biakan bakteri di laboratorium bioteknologi FMIPA UNJ}

Bakteri biakan yang diperoleh dari Laboratorium GBF dan Mikrobiologi UI selanjutnya dibiakkan dan diremajakan di Laboratorium Biokimia-bioteknologi FMIPA UNJ sebagai bakteri uji.

\section{a. Pembiakan Bakteri pada Media Nutrient Broth cair}

Bakteri uji yang diperoleh dari laboratorium vaccine group dalam bentuk liofilisasi. Untuk penumbuhan bakteri tersebut dilakukan tahap sebagai berikut: biakan bakteri hasil liofilisasi diambil dengan tusuk gigi steril (ujung tusuk gigi ditempelkan pada bakteri hasil liofilisasi). Kemudian tusuk gigi dicelupkan pada $5 \mathrm{~mL}$ media Nutrient broth cair steril yang telah ditempatkan pada tabung reaksi. Selanjutnya tabung reaksi yang berisi media dan bakteri diinkubasi pada suhu $37^{\circ} \mathrm{C}$ selama 16-18 jam dengan aerasi shaker sebesar $150 \mathrm{rpm}$. Hasil penumbuhan bakteri dicek dengan melihat kekeruhan yang timbul setelah 16-18 jam inkubasi, makin keruh media menunjukkan bakteri dapat tumbuh dengan baik. Semua proses penumbuhan bakteri dilakukan pada Laminar air flow steril.
Bakteri uji yang diperoleh dari laboratorium mikrobiologi UI adalah dalam media agar miring. Pelaksanaan peremajaan bakteri-bakteri pada penelitian ini ditempuh cara sebagai berikut: biakan bakteri pada agar miring diambil dengan kawat ose steril (satu koloni atau gores ose). Kemudian kawat ose steril yang telah ditempelkan pada bakteri dari agar miring dicelupkan pada $5 \mathrm{~mL}$ media Nutrient broth cair steril yang telah ditempatkan pada tabung reaksi. Selanjutnya tabung reaksi yang berisi media dan bakteri diinkubasi pada suhu $37^{\circ} \mathrm{C}$ selama $16-18$ jam dengan aerasi shaker sebesar $150 \mathrm{rpm}$. Hasil penumbuhan bakteri dicek dengan melihat kekeruhan yang timbul, makin keruh media menunjukkan bakteri dapat tumbuh dengan baik. Semua proses penumbuhan bakteri dilakukan pada Laminar air flow steril.

b. Pembiakan bakteri pada Nutrient Agar

Kawat ose steril dicelupkan pada biakan bakteri cair hasil penumbumbuhan pada tahap sebelumnya. Selanjutnya kawat ose tersebut digoreskan dengan cara zig-zag pada media nutrient agar steril yang telah disiapkan. Media nutrient agar yang telah mengandung bakteri diinkubasi 16-18 jam pada inkubator pada suhu $37^{\circ} \mathrm{C}$. Hasil penumbuhan bakteri di cek setelah proses inkubasi selama 16-18 jam.

\subsection{Isolasi genom bakteri Gram negatif dan karakterisasinya}

a. Isolasi genom bakteri Gram negatif

Tahapan yang ditempuh untuk proses isolasi DNA genome bakteri adalah sebagai berikut: $1 \mathrm{~mL}$ biakan bakteri yang telah ditumbuhkan 16-18 jam (overnight culture) dimasukkan pada tabung microcentrifuge eppendorf $1.5 \mathrm{~mL}$. Tabung eppendorf yang berisi biakan bakteri disentrifugasi pada 13,000-16,000 g selama 2 menit sampai dihasilkan pellet sel. Supernatan dikeluarkan dengan cara menuangkan sisa media beaker glass sebagai penampung yang sudah diberi disinfektan. Selanjutnya pellet yang diperoleh ditambahkan $600 \mu \mathrm{l}$ Nuclei Lysis Solution. Pellet diresuspensi dengan cara pemipeten naik turun dari campuran tersebut sampai terlihat homogen. Campuran diinkubasi pada $80^{\circ} \mathrm{C}$ selama 5 menuit untuk melisis sel 
bakteri. Kemudian didinginkan pada suhu kamar. Setelah mencapai suhu kamar, selanjutnya ditambahkan $3 \mu 1$ RNase Solution pada cairan lysat bakteri. Tabung dibolakbalik 2-5 kali untuk menghomogenkan campuran. Selanjutnya tabung diinkubasi pada suhu $37^{\circ} \mathrm{C}$ selama $15-60$ menit, untuk mengoptimalkan kerja enzim RNAse. Setelah itu sampel didinginkan kembali pada suhu kamar. Campuran sel bakteri yang telah ditretment dengan RNAse dan diinginkan pada suhu kamar ditambahkan lagi dengan $200 \mu 1$ Protein Precipitation Solution. Campuran di vortex selama 20 detik pada kecepatan tinggi untuk menghomogenkan Protein Precipitation Solution dengan lysat sel bakteri. Kemudian campuran tersebut diinkubasi pada es selama 5 menit. Setelah diinkubasi selanjutnya dilakukan sentrifugasi campuran pada 13,000-16,000 g selama 3 menit. Supernatan hasil sentrifugasi diambil secara hati-hati jangan sampai pellet selnya/residu proteinnya terbawa, kemudian dimasukkan pada tabung eppendorf $1,5 \mathrm{~mL}$ steril yang telah diisi dengan $600 \mu \mathrm{l}$ isopropanol pada suhu kamar. Tabung yang berisi campuran selanjutnya dibolak-balik sampai terlihat terlihat benang-benang halus dari DNA terlihat. Kemudian tabung disentrifugasi pada $13,000-16,000$ g selama 2 menit. Hati-hati keluarkan supernatannya dan keringkan tabung dengan cara membalikkan tabung di atas kertas adsorbent seperti tissue bersih. Tabung yang mengandung pellet DNA ditambah dengan $600 \mu$ letanol $70 \%$ pada suhu ruang, kemudian tabung dibolak-balik $2-5 \mathrm{x}$ untuk melakukan proses pencucian pellet DNA. Selanjutnya tabung yang mengandung lysat DNA disentrifugasi pada $13,000-16,000$ $\times$ g selama 2 menit. Secara hati-hati etanol dikeluarkan dengan cara pemipetan perlahanlahan. Sentrifugasi bisa dilakukan lebih dari satu kali untuk memastikan tidak ada lagi alkohol tersisa pada tabung. Tabung eppendorf yang berisi pellet DNA dikeringanginkan dengan cara dibalik di atas kertas tissue bersih. Pellet dibiarka kering selama 10-15 menit. Selanjutnya tabung yang berisi pellet DNA ditambah dengan $100 \mu \mathrm{l}$ DNA Rehydration Solution untuk melarutkan DNA dan didikubasi pada $65^{\circ} \mathrm{C}$ selama 1 jam. Secara periodik pada masa inkubasi lakukan homogenisasi larutan dengan cara tapping the tube atau menyentuh bagian eppendorf dengan ibu jari hingga larutan homogen. Alternatif lain, inkubasi larutan DNA dapat dapat dilakukan pada suhu kamar atau pada suhu $4^{\circ} \mathrm{C}$ selama semalam. Hasil isolasi larutan DNA genome bakteri ini selanjutnya disimpan pada suhu $2-8^{\circ} \mathrm{C}$.

Tabel 1. Hasil perancangan Fimbrial chaperon S. typhi C.T 18 Protein (MS 3602)

\begin{tabular}{|c|c|c|c|c|c|c|c|c|c|}
\hline No. & PRIMER & NAME & $\begin{array}{l}\text { LENGT } \\
\text { H BP }\end{array}$ & SEQUENCE & $\begin{array}{l}\text { BASE } \\
\text { PAIRS }\end{array}$ & SCALE & $\% G C$ & $\begin{array}{l}\mathrm{TM} \\
{ }^{\mathrm{O}} \mathrm{C}\end{array}$ & MW \\
\hline 1. & FW-1B & $\begin{array}{l}\text { STPF- } \\
1 \mathrm{~B}\end{array}$ & 783 & $\begin{array}{l}\text { 5' CGC TGG TTT ACC } \\
\text { CAT GAA TTT TCT TGC } \\
\text { CGA 3' }\end{array}$ & 30 & $0.01 \mu \mathrm{mol}$ & 46.7 & 66.8 & 9138.9 \\
\hline 2. & $\begin{array}{l}\text { REV-1A } \\
\text { NEW }\end{array}$ & $\begin{array}{l}\text { STPR- } \\
1 \mathrm{~A}\end{array}$ & 783 & $\begin{array}{l}\text { 5' GGT TGT CTT CTT } \\
\text { CAT CGT GTT CTC GTG } \\
\text { TGG 3' }\end{array}$ & 30 & $0.01 \mu \mathrm{mol}$ & 50 & 68.1 & 9207.9 \\
\hline 3. & $\begin{array}{l}\text { REV-iNT } \\
1 \mathrm{NEW}\end{array}$ & STPRI-1 & 165 & $\begin{array}{l}\text { 5' GCG TCT TCC GGC } \\
\text { GTC TGC GGC AAA T } 3\end{array}$ & 25 & $0.01 \mu \mathrm{mol}$ & 64 & 69.5 & 7649.9 \\
\hline 4. & FW-INT 2 & STPFI-2 & 223 & $\begin{array}{l}\text { 5' GGT CAA TAT CAG } \\
\text { CGT GGG TGC GAA A 3' }\end{array}$ & 25 & $0.01 \mu \mathrm{mol}$ & 52 & 64.6 & 7771.1 \\
\hline
\end{tabular}


b. Karakterisasi DNA Genome bakteri dengan elektroforesis gel agarose

Karakterisasi hasil isolasi genome bakteri dilakukan dengan elektroforesis gel agarose $1 \%$ dengan pewarna Etidium Bromida. Masing-masing $5 \quad \square \mathrm{L} \quad$ DNA genome dicampurkan dengan $7 \square$ L loading dye buffetr 1x. Proses elektroforesis dilakukan pada kondisi 80 volt selama 1 jam atau 70 volt 1.5 jam. Visualisasi hasil elektroforesis dilakukan di bawah lampu UV dengan panjang gelombang $260 \mathrm{~nm}$.

\subsection{Amplifikasi genom S. typhi dengan primer spesifik}

Amplifikasi gen-fimC S. typhi dilakukan dengan PCR gradien pada kondisi stpesifik dengan nama program A-27 (Muti). Tahap amplifikasi didisain melalui beberapa tahap yaitu : (1) tahap preparasi kondisi $95{ }^{\circ} \mathrm{C}$ selama 5 menit, (2) tahap denaturasi $95{ }^{\circ} \mathrm{C}$ selama 1 menit, (3) tahap annealing adalah gradien 15 mulai dari suhu $55{ }^{\circ} \mathrm{C}-69.7{ }^{\circ} \mathrm{C}$ selama 1 menit, (4) tahap pemanjangan rantai pada suhu $72{ }^{\circ} \mathrm{C}$ selama 1 menit, dan tahap pemantapan produk pada suhu $72{ }^{\circ} \mathrm{C}$ selama 7 menit. Jumlah siklus sebanyak 32 siklus dan dilakukan pada suhu ruang $\left(25^{\circ} \mathrm{C}\right)$.

\subsection{Karakterisasi Hasil PCR dengan elektroforesis gel agarose}

Karakterisasi hasil amplifikasi dilakukan dengan elektroforesis gel agarose 1,5\% dengan pewarna syber-Green. Proses elektroforesis dilakukan pada kondisi 80 volt selama 1 jam. Visualisasi hasil elektroforesis dilakukan di bawah lampu UV dengan panjang gelombang $260 \mathrm{~nm}$.

\section{Hasil dan Pembahasan}

\subsection{Disain dan Sintesis Primer gen fim-c S. typhi}

Pada tahap penelitian sebelumnya primer didisain langsung dari urutan gen fim-C $S$. typhi. Perancangan primer dilakukan dengan memperhatikan syarat-syarat standar, diantaranya adalah panjang primer 20-30 nukleotida, memiliki \% GC di atas 50, tidak terjadi primer dimer, dan memastikan dengan cermat arah reverse dan forwardnya.

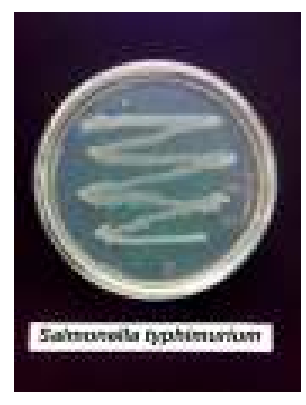

4

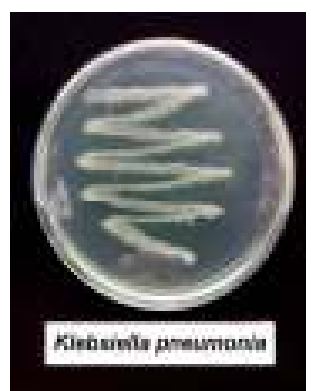

5

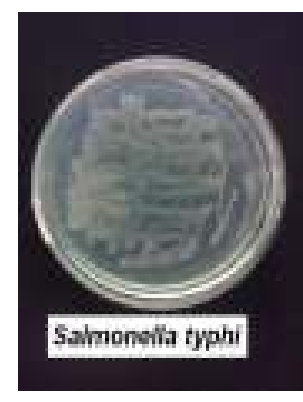

6

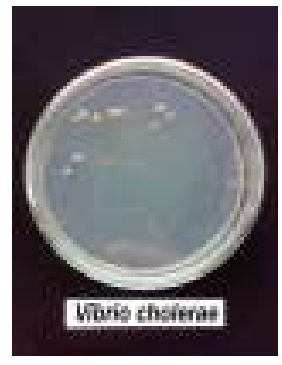

4

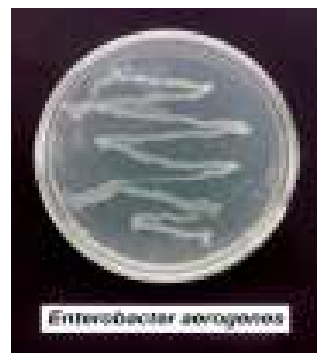

5

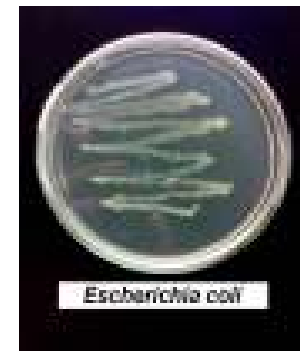

6

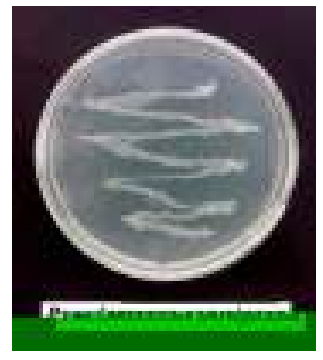

7

Gambar 1. Tujuh bakteri uji hasil penumbuhan. Foto 1 adalah bakteri Salmonella typhimurium LT2 ATCC dari GBF. Foto 2 adalah bakteri Klebsiella Pneumonia. Foto 3 adalah bakteri Salmonella typhi. Foto 4 adalah bakteri Vibrio cholera. Foto 5 adalah bakteri Enterobacter aerogenes. Foto 6 adalah bakteri Escherichia coli dan Foto 7 adalah bakteri Pseudomonas aeruginosa. Bakteri pada foto 2-7 berasal dari lab Mikrobilogi Universitas Indonesia. 
Berdasarkan syarat-syarat tersebut telah dirancang dua buah primer forward (memiliki arah 5'-3') dan dua buah primer reverse (memiliki arah 3'-5'). dua buah primer forward tersebut masing-masing diberi kode fw-1b (30 nukleotida) dan fw-int 2 (25 nukleotida). sedangkan primer reveres masing-masing diberi kode rev-1a new (30 nukleotida) dan rev-int 1 new (25 nukleotida). urutan primer gen fimbriae $S$. typhi hasil rancangan secara detail disajikan pada tabel1.

Setelah dilakukan proses perancangan primer secara in scripto selanjutkan dilakukan proses sintesis primer gen fim-c, untuk memperoleh molekul primer yang akan digunakan pada proses amplifikasi gen fim-c S. typhi, yang secara spesifik dapat mengamplifikasi fragmen gen dengan ukuran sesuai dengan yang diharapkan. Sintesis primer dilakukan oleh Company Eurofins MWG GmbH-Jerman [MWG GmbH, 2008].

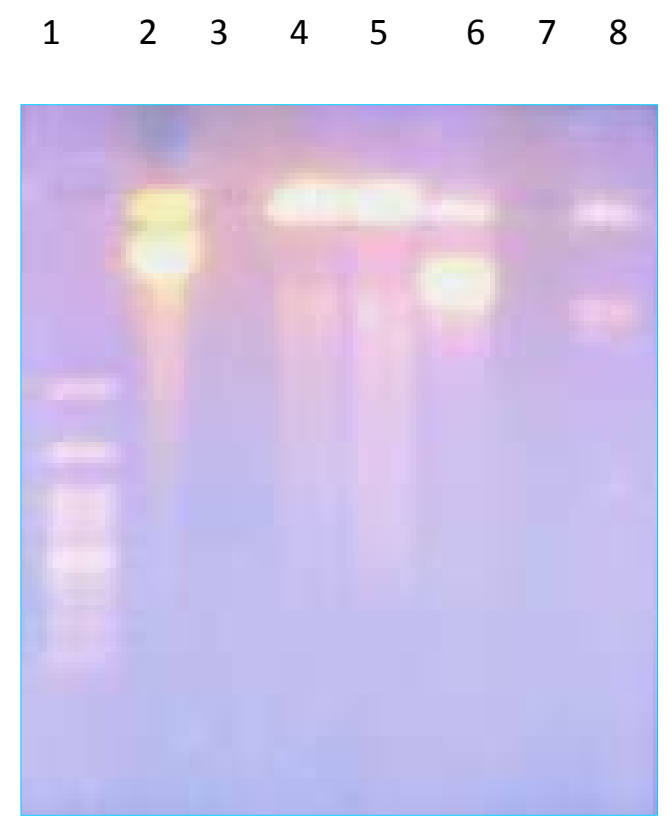

Gambar 2. Hasil elektroforesis genome bakteri uji. Kolom 1. Marker DNA 1kb Ladder, kolom 2. DNA Genome S. typhi, kolom 3. DNA genome Vibrio cholera (-), kolom 4. DNA genom S. typhimurium, kolom 5. DNA genom E.coli, kolom 6 DNA genom Enterobacter aerogenes, kolom 7. DNA genom pseudomonas aeruginosa ( -), kolom 8. DNA genome Klebsiella pneumonia. Elektroforesis dilakukan pada 80 volt 1 jam, dengan pewarna etidium bromida, dan visualisasi dilakukan dengan bantuan lampu UV 256 $\mathrm{nm}$.
3.2 Penumbuhan biakan bakteri di laboratorium bioteknologi FMIPA UNJ

Penelitian ini telah berhasil menumbuhkan bakteri uji pada kondisi standar baik pada media cair maupun media padat. Peralatan pada laboratorium bioteknologi yang digunakan pada penelitian ini merupakan hasil sumbangan dari DAAD Jerman pada program Equipment Grant untuk alumni Jerman, yang diusulkan bersama oleh peneliti dan rekan dari jurusan biologi FMIPA UNJ. Sehingga penelitian ini merupakan penelitian pertama yang memanfaat kan peralatan tersebut.

Hasil penumbuhan bakteri pada media cair telah berhasil dilakukan, hal ini ditunjukkan dengan tumbuhnya bakteribakteri uji pada media nutrient broth. Tumbuhnya bakteri tersebut ditandai dengan keruhnya media pertumbuhan dibandingkan dengan media tanpa bakteri.

Hasil penumbuhan bakteri pada nurtrien agar ditunjukkan dengan tumbuhnya kolonikoloni bakteri pada permukaan media agar. Beberpa foto hasil penumbuhan bakteri pada media nutrient agar disajikan pada gambar 1 .

\subsection{Isolasi genom bakteri Gram negatif}

Isolasi DNA genome bakteri dengan menggnunakan kit isolasi Wizard telah berhasil dilakukan untuk enam galur bakteri yaitu Salmonella typhimurium LT2 ATCC, Klebsiella pneumonia, Salmonella typhi, Enterobacter aerogenes, Escherichia coli, pseudomonas aeruginosa. Foto hasil isolasi genom bakteri uji disajikan pada gambar 2 .

Berdasarkan data yang diperoleh pada gambar 4.2 menunjukkan bahwa DNA genome bakteri vibrio cholera dan pseudomonas tidak dapat terdeksi, atau memebri hasil negatif. Isoalsi selanjutnya dilakukan pengulangan untuk kedua bakteri tersebut dan diperoleh hasil yang sama dengan bakteri lainnya (hasil elektroforesis kedua bakteri tersebut tidak ditampilkan kembali). Pita DNA bakteri uji memiliki posisi yang lebih tinggi dari garis pertama DNA marker 1 $\mathrm{kb}$ Ladder. Ini menunjukkan bahwa ukuran DNA bakteri uji lebih besar dari $1 \mathrm{~kb}$. Hal ini sesuai dengan hasil pencarian informasi 
tentang genome ke tujuh bakteri tersebut dari beberapa genome database dan publikasi tentang penentuan urutan genome bakteri. Hasil analysis data dari beberapa literatur menunjukkan bahwa ukuran masing-masing DNA genome ketujuh bakteri tersebut berturut-turut sebagai berikut : Bakteri $S$. typhi 4,81 mega basa (mb), S. typhimurium 4,85 mb, E. Coli 4,69 mb, Enterobacter 4,52 $\mathrm{mb}$, Vibrio cholera $2,89 \mathrm{mb}$, Klebsiella. $P$ 5,64 $\mathrm{mb}$ dan Pseudomonas.A. 6,60 mb. Gambar masing-masing sirkular genome bakteri dan ukurannya disajikan pada gambar 3.

Adanya 2 buah pita menunjukkan bahwa bentuk DNA genom ke tujuh bakteri uji adalah berbentuk sirkular, bentuk tersebut dalam elektroforesis agarosa memiliki pola 2 buah garis. Sehingga hasil yang diperoleh sesuai dengan literatur standar tentang bentuk genome bakteri. Berdasarkan data-data di atas maka penelitian ini telah berhasil melakukan isolasi DNA genom ke tujuh bakteri di atas, yaitu S. typhi, S. typhimurium, E. Coli, Enterobacter, Vibrio cholera, Klebsiella. P dan Pseudomonas. A dengan ukuran yang sesuai [J. Parkhill et al, 2001; Mcclelland M et al, 2001; Hayashi K, et al, 2006; Durfee T et al, 2008; Feng L et al, 2008; Fouts DE et al, 2008; NCBI Genome bacteria database, 2009].

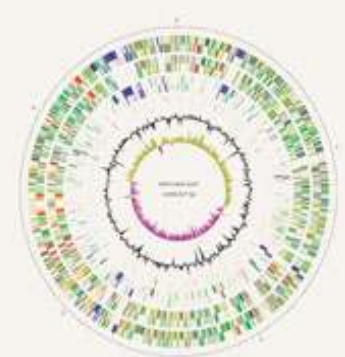

\section{S. tvphi Genome}

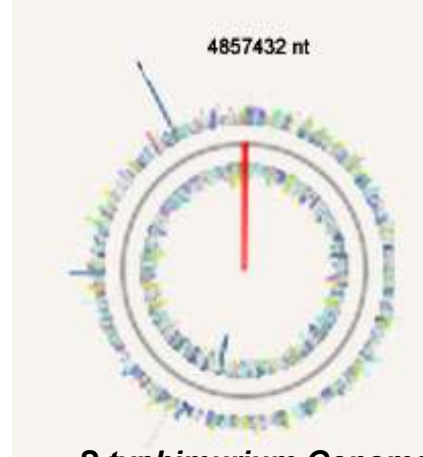

S.typhimurium Genome

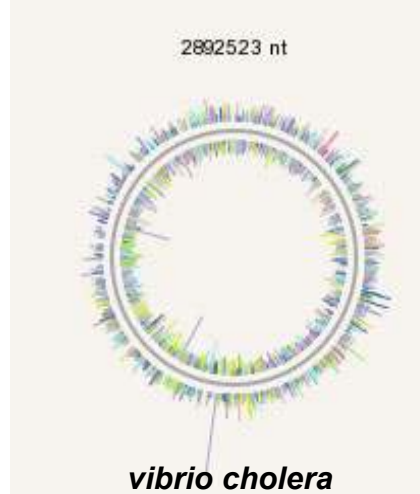

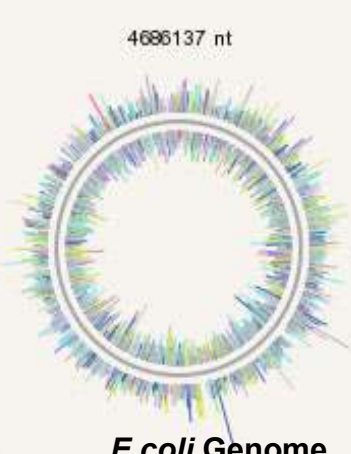

Froli Gennme

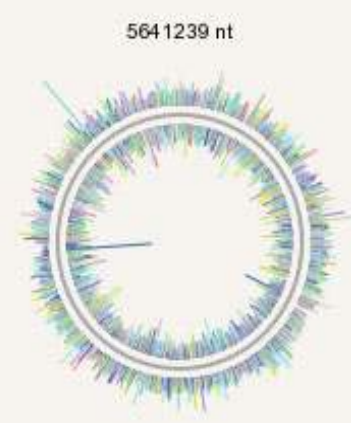

Klebsiella $P$. Genome

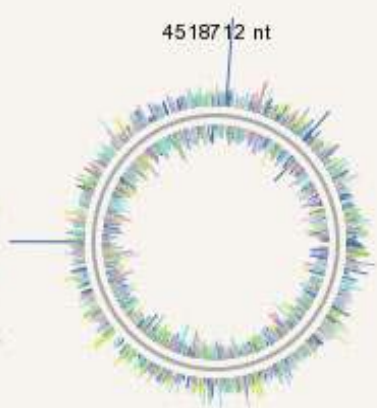

Enterobacter

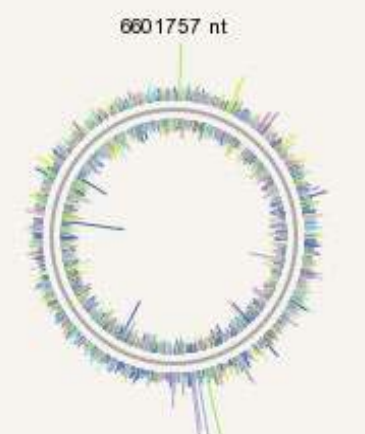

Pseudomonas.A. Genome

Gambar 3. Representasi circular genome tujuh bakteri. Bakteri S. typhi memiliki ukuran genom 4,81 mega basa (mb), S. typhimurium 4,85 mb, E. Coli 4,69 mb, Enterobacter 4,52 mb, Vibrio cholera 2,89 $\mathrm{mb}$, Klebsiella. P 5,64 mb dan Pseudomonas. A. 6,60 mb. 


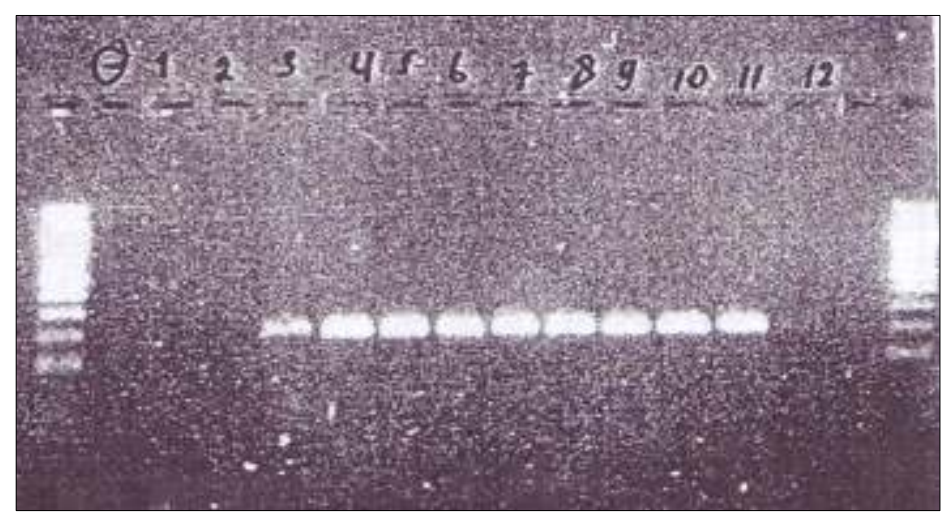

Gambar 4. Hasil amplifikasi gen struktural fim-c S. typhi. Hasil dokumentasi menunjukkan produk PCR dengan pasangan primer fw-int 2- rev-1a new. produk PCR yang dihasilkan adalah $0.2 \mathrm{~kb}$. Penampakan hasil dilakukan dengan elektroforesis gel agarosa 1,5\% yang mengandung syber green. visualisasi hasil elektroforesis dilakukan dengan bantuan sinar uv pada panjang gelombang $256 \mathrm{~nm}$.

3.4 Amplifikasi gen fim-c bakteri $S$.typhi dengan teknik PCR dan Karakterisasi dengan elektroforesis gel agarose

Melalui proses amplifikasi dengan teknik polymerase chain reaction gradien (PCRgradien) pada kondisi $95^{\circ} \mathrm{c}$ selama 5 menit, denaturasi $95^{\circ} \mathrm{c}$ selama 1 menit, annealing mulai dari suhu $55^{\circ} \mathrm{c}-69.7^{\circ} \mathrm{c}$ selama 1 menit, tahap pemanjangan rantai pada suhu $72^{\circ} \mathrm{c}$ selama 1 menit, dan tahap pemantapan produk pada suhu $72{ }^{\circ} \mathrm{c}$ selama 7 menit, jumlah siklus 32 dan menggunakan templat kromosom $S$. typhi dengan pasangan primer $\mathrm{Fw}$-int 2- Rev1a new telah berhasil diamplifikasi fragmen DNA berukuran $193 \mathrm{pb}$ atau $(0,2 \mathrm{~kb})$. adanya pita tersebut pada suhu tertentu menunjukkan bahwa pasangan primer fw-int 2- rev-1a new hasil rancangan dan sintesis dapat digunakan untuk proses amplifikasi, karena pasangan primer ini dirancang membatasi daerah gen fimbrea-c S. typhi dengan ukuran $193 \mathrm{pb}$.

Kesesuaian antara hasil rancangan secara in scripto dan hasil amplifikasinya merupakan langkah awal untuk melakukan tahap penelitian selanjutnya, baik pada tingkat genomik mapun proteomik. Dokumentasi hasil PCR gradien dengan pasangan primer fw-int 2- rev-1a new dengan panjang fragmen $193 \mathrm{pb}$ melalui elektroforesis gel agarosa disajikan pada gambar 4 .

2.5 Pengkajian pengembangan metode deteksi yang dihasilkan terhadap beberapa metode deteksi lainnya

Sampai saat ini telah banyak tes dikembangkan untuk melakukan diagnosa terhadap bakteri penyebab penyakit typhus. Seperti telah diuraikan pada kajian pustaka beberapa tes yang dikembangkan masih memiliki kekurangan-kekurangan, sehingga masih terus dikembangkan dan dilakukan penemuan terhadap metode deteksi yang sensitif, spesifik dan akurat.

Metode deteksi yang dipakai saat ini umumnya adalah metode serologi. Metode pemeriksaan serologis imunologis ini dikatakan mempunyai nilai penting dalam proses diagnostik demam tifoid. Akan tetapi masih didapatkan adanya variasi yang luas dalam sensitivitas dan spesifisitas pada deteksi antigen spesifik $S$. typhi oleh karena tergantung pada jenis antigen, jenis spesimen yang diperiksa, teknik yang dipakai untuk melacak antigen tersebut, jenis antibodi yang digunakan dalam uji (poliklonal atau monoklonal) dan waktu pengambilan spesimen (stadium dini atau lanjut dalam perjalanan penyakit).

Beberapa kekurangan yang dapat ditimbulkan oleh masing-masing metode deteksi tersebut adalah sebagai berikut : (1). Uji Widal ; Kelemahan uji Widal yaitu rendahnya sensitivitas dan spesifisitas serta sulitnya melakukan interpretasi hasil membatasi penggunaannya dalam penatalaksanaan penderita demam tifoid akan tetapi hasil uji Widal yang positif akan memperkuat dugaan pada tersangka penderita demam tifoid (penanda infeksi). Saat ini walaupun telah digunakan secara luas di seluruh dunia, manfaatnya masih diperdebatkan dan sulit dijadikan pegangan karena belum ada kesepakatan akan nilai standar aglutinasi (cut-off point). Untuk mencari standar titer uji Widal seharusnya 
ditentukan titer dasar (baseline titer) pada anak sehat di populasi dimana pada daerah endemis seperti Indonesia akan didapatkan peningkatan titer antibodi $\mathrm{O}$ dan $\mathrm{H}$ pada anak-anak sehat. (2). tes TUBEX®: Walaupun belum banyak penelitian yang menggunakan tes TUBEX ${ }^{\circledR}$ ini, beberapa penelitian pendahuluan menyimpulkan bahwa tes ini mempunyai sensitivitas dan spesifisitas yang lebih baik daripada uji Widal. 3. ELISA :Uji ELISA yang sering dipakai untuk mendeteksi adanya antigen $S$. typhi dalam spesimen klinis adalah double antibody sandwich ELISA. Pemeriksaan terhadap antigen Vi urine ini masih memerlukan penelitian lebih lanjut akan tetapi tampaknya cukup menjanjikan, terutama bila dilakukan pada minggu pertama sesudah panas timbul, namun juga perlu diperhitungkan adanya nilai positif (false positif) pada kasus dengan Brucellosis.

Metode deteksi S. typhi yang dikembangkan pada penelitian ini adalah metode deteksi dengan Polymerase chain reaction (PCR). Metode PCR adalah teknik yang secara luas digunakan dalam molecular biology. Nama polymerase diturunkan dari salah satu komponen dalam proses tersebut yaitu enzim DNA polymerase, yang digunakan untuk mengamplifikasi DNA secara in vitro. Sedangkan chain reaction adalah karena proses amplifikasi yang dilakukan oleh enzim polymerase dari DNA template berlangsung secara exponential. Metode PCR dapat digunakan untuk mengamplifikasi satu molekul atau sedikit copy dari molekul DNA menjadi miliaran copy, sehingga memungkinkan penggunaannya dalam bidang yang lebih luas.

Keuntungan metode deteksi dengan teknik PCR dapat diuraikan sebagai berikut (1) Jumlah sampel yang digunakan sangat kecil, karena hanya memerlukan beberapa copy molekul DNA, bahkan dapat dilakukan untuk sampel yang hanya mengandung 1 copy molekul DNA. (2) Sampel dapat berasal dari berbagai spesimen yang mengandung bakteri $S$. typhi, sehingga penggunaan sampel dapat dilakukan pada range yang luas. (3) Bersifat spesifik, karena dengan metode PCR hanya akan diamplifikasi fragment DNA sesuai dengan daerah yang dibatasi oleh primer. (4) Hasil yang diperoleh sangat akurat, karena primer yang didisain didasarkan pada urutan DNA bakteri uji. (5) Bersifat sensitif, karena dengan jumlah copy molekul DNA sudah dapat mendeteksi bakteri uji. (6) Waktu deteksi relatif cepat dibanding metode serologi. Beberapa kelemahan yang ada dengan metode deteksi dengan PCR adalah (1) Penggunaan metode PCR memerlukan tenaga ahli yang khusus. (2) Peralatan dan bahan yang digunakan sebagai media uji masih relatif mahal.

Melihat banyaknya keuntungan pengembagan metode deteksi dengan PCR, maka potensi pengembangan metode deteksi ini sangat potensial untuk meningkatkan kualitas kesehatan masyarakat. Makin cepat seorang pasien diketahui penyakitnya, maka makin cepat pula dokter dapat memberikan treatment yang terbaik dan mengobati penyakit yang diderita pasien. Walaupun masih ada kendala dalam sumber daya manusia (SDM) dan pendanaan namun hal ini dapat diatasi secara bertahap dalam bentuk investasi sumber daya manusia dan investasi peralatan. Berdasarkan pengkajian tersebut maka dapat disimpulkan bahwa pengembangan metode deteksi penyakit typhus dengan metode PCR, melalui deteksi gen fim-C S. typhi dapat dijadikan landasan untuk penyempurnaan metode deteksi yang telah ada.

\section{Kesimpulan dan Saran}

\subsection{Kesimpulan}

a. Penelitian ini telah berhasil mengamplifikasi gen fimbrial-C S. typhi menggunakan pasangan primer hasil perancangan yaitu FW-INT 2- REV-1A NEW. Keberhasilan tersebut ditunjukkan dengan diperolehnya pita DNA berukuran 0.2 kilo basa $(\mathrm{kb})$ sesuai dengan ukuran pita DNA yang diharapkan dengan menggunakan template DNA genom bakteri S. typhi.

b. Adanya pita DNA berukuran 0.2 kilo basa (kb) gen fim-C S. typhi juga menunjukkan bahwa penelitian ini telah berhasil melakukan pengembangan metode deteksi penyakit typhus dengan metode PCR. Pengembangan metode ini dapat dijadikan landasan untuk penyempurnaan metode deteksi yang telah ada.

c. Penelitian ini juga telah berhasil menumbuhkan dan mengisolasi DNA genome tujuh bakteri uji yaitu $S$. typhi; Salmonella typhimurium LT2 ATCC; bakteri Klebsiella Pneumonia; bakteri Vibrio cholera; bakteri Enterobacter aerogenes; bakteri Escherichia coli dan bakteri Pseudomonas aeruginosa, baik 
pada media cair maupun pada media padat. Hal ini ditunjukkan dengan tumbuhnya bakteri-bakteri uji pada media nutrient broth. Tumbuhnya bakteri tersebut ditandai dengan keruhnya media pertumbuhan dibandingkan dengan media tanpa bakteri. Hasil penumbuhan bakteri pada nurtrien agar ditunjukkan dengan tumbuhnya koloni-koloni bakteri pada permukaan media agar.

\subsection{Saran}

Reprodusibilitas suatu alat deteksi merupakan kriteria yang sangat penting. Berdasarkan hal tersebut maka penelitian ini harus dilanjutkan pada uji spesifisitas dan sensitifitas alat deteksi tersebut untuk memperoleh alat deteksi yang baik dan memenuhi persyaratan sebagai alat deteksi. (2) Diperlu penelitian lanjutan baik untuk pengembangan kualitas alat uji maupun pengurusan paten. (3) Diperlukan penelitian lanjutan dalam pengembangan ekspresi gen fim-C S. typhi menjadi proteinnya yang potensial sebagai kandidat vaksin terhadap penyakit typhus pada manusia.

\section{Penghargaan}

Penelitian ini dibiayai oleh Lembaga Penelitian UNJ, Ucapan terimakasih kami haturkan kepada Prof. Dr. Rer. Nat. Sentot Santoso, dari Laboratorium Immunologi Justus Liebig Universitat- Giessen Jerman, Laboratorium Vaccine Group GBF-Germany atas segala saran dan bantuannya sehingga penelitian dapat berjalan lancar.

\section{Daftar Pustaka}

Bernard,I., (1997) Typhoid fever : a global overview, Medical Journal of Indonesia, Proceedin of the third Asia-Pasific Symposium on Typhoid Fever and other Salmonellosis. Denpasar Indonesia, 7, 5-8.

Dunbar, B.S., Kimura, H. \& Timmons, T.M. (1990), Protein analysis using high resulation two dimensional polyacrylamide gel electrophoresis. In: Guide to protein purification. Deutscher, M.P (ed). Academic Press Inc. San Diego. pp. 441-459.

Deutsher, P, Murray., (1990) Guide to Protin Purification, 182, 668-673.

Durfee T, Nelson R, Baldwin S, Plunkett G 3rd, Burland V, Mau B, Petrosino Jf, Qin X, Muzny Dm, Ayele M, Gibbs RA, Csörgo B, Pósfai G, Weinstock Gm, Blattner Fr, 2008. The Complete Genome Sequence Of Escherichia Coli DH10B: insights into The Biology Of a Laboratory workhorse. Bacteriol. 2008 Apr;190(7):2597-606. Epub 2008 Feb 1.

Feng L, Reeves PR, Lan R, Ren Y, Gao C, Zhou Z, Ren Y, Cheng J, Wang W, Wang J, Qian W, Li D, Wang L.2008. A recalibrated molecular clock and independent origins for the cholera pandemic clones. PLoS One. 2008;3(12):e4053. Epub 2008 Dec 30

Fernandez, J., Gharahdaghi, F. \& Mische, S.M. (1998), Routine identification of protein from sodium dodecyl sulfate-polyacrylamide gel electrophoresis (SDS-PAGE) gels or polyvinyl difluoride membranes using matrix assisted laser desorption/ionization-time of flight-mass spectrometry (MALDI-TOF-MS). Electrophoresis, 19:1036-1045.

Fouts DE, Tyler HL, Deboy RT, Daugherty S, Ren Q, Badger JH, Durkin AS, Huot H, Shrivastava S, KOTHARI S, Dodson RJ, Mohamoud Y, Khouri H, Roesch LF, Krogfelt KA, Struve C, triplett EW, Methé BA. 2008. Complete Genome Sequence of the N2-fixing Broad Host Range Endophyte Klebsiella Pneumoniae 342 and Virulence Predictions Verified in Mice. PLoS Genet. 2008 Jul 25;4(7):E1000141.

Glaser, P., Frangeul L, Buchrieser C, Rusniok C, Amend A, Baquero F, Berche P, Bloecker H, Brandt P. 2001. Comparative genomics of Listeria species. Science 2001;294(5543): 849852. 
Henikoff, J.G., Pietrokovski, S., McCallum, C.M., Henikoff, S. (2000). Block-based method for detecting protein homology. Electrophoresis, 21:1700-1706.

Hayashi, M., Hideshi Kouzu, Masahiro Nishihara, Tohru Takahashi, Masato Furuhashi, Ken-ichi Sakamoto, Naotoshi Satoh, Takahiro Nishitani, \& Yasukuni Shikano. 2005. Acute Renal Failure Likely due to Acute Nephritic Syndrome Associated with Typhoid Fever. Internal Medicine 2005;44(10): 1074-1077.

Hayashi K, Morooka N, Yamamoto Y, Fujita K, Isono K, Choi S, Ohtsubo E, Baba T, Wanner BL, Mori H, Horiuchi T. 2006. Highly accurate genome sequences of Escherichia coli K12 strains MG1655 and W3110. Mol Syst Biol. 2006;2:2006-2007. Epub 2006 Feb 21.

Hirose, K., Kazumichi Tamura, \& Haruo Watanabe. 2003. Screening Method for Salmonella enterica Serovar Typhi and Serovar Paratyphi A with Reduced Susceptibility to Fluoroquinolones by PCR-Restriction Fragment Length Polymorphism. Microbiol. Immunol 2003;47(2): 161-165.

J. Parkhill, G. Dougan, K. D. James, N. R. Thomson, D. Pickard, J. Wain, C. Churcher, K. L. Mungall, S. D. Bentley, M. T. G. Holden, M. Sebaihia, S. Baker, D. Basham, K. Brooks, T. Chillingworth, P. Connerton, A. Cronin, P. Davis, R. M. Davies, L. Dowd, N. White, J. Farrar, T. Feltwell, N. Hamlin, A. Haque, T. T. Hien, S. Holroyd, K. Jagels, A. Krogh, T. S. Larsen, S. Leather, S. Moule, P. Ó'Gaora, C. Parry, M. Quail, K. Rutherford, M. Simmonds, J. Skelton, K. 2001. Complete genome sequence of a multiple drug resistant Salmonella enterica serovar Typhi CT18. Nature 413, 848-852

Mahan, M.J., Saluch and J.J. Mekalanos, (1993), Selection of bacterial virulence genes that are specially induced in host tisues, Science, 259, 686-688.

Mc Clelland M, Sanderson KE, Spieth J, Clifton SW, Latreille P, Courtney L, Porwollik S, Ali J, Dante M, Du F, Hou S, Layman D, Leonard S, Nguyen C, Scott K, Holmes A, Grewal N, Mulvaney E, Ryan E, Sun H, Florea L, Miller W, Stoneking T, Nhan M, Waterston R, Wilson RK. Complete Genome Sequence Of Salmonella Enterica Serovar Typhimurium LT2. Nature. 2001 OCT 25; 413(6858):852-6.

Muktiningsih, A.S. Noer, E. Purwantini, A. Rudiretna, Oei Ban Liang. (2001) Production of Anti-Car A Antibodies of Salmonella typhi for the carA Gene In Vivo Expression Study. The second International Biotechnoloi Conference. Yogjakarta, Indonesia. (Inpres)

Muktiningsih. 2005. Produk Gen carA Salmonella typhi Berukuran 42 kDa yang Dideteksi dengan Antibodi Anti-Protein Fusi. Disertasi. Program Pascasarjana, Institut Teknologi Bandung.

Muktiningsih, Aceng. R, Dastam, A., Yoni. F. S., Supriyadi, S., dan Deiwick, J. 2006. Mapping of Salmonella typhi Proteins Based On Proteomic Analysis Technology As an Effort to Discover Bioactive Protein, Proceeding Asean Biochemistry Seminar 2006:44-51.

Muktiningsih, Yoni.F. Syukriani, Irma Ratna Kartika, 2009. Studi Fungsi Protein Reference Spot Salmonella typhi. Laporan Penelitian Fundamental. Ditjen DIKTI. Jakarta

Peterson, G.1. 1977. A simplification of the protein assay method of Lowry et al. which is generally applicable. Analyt. Biochem. 83: 346-356.

Rudiretna, A., (1998) Gen Mirip car A Pada salmonella typhi. Disertasi Program Pascasarjana, ITB 
Ruyani, A., Sudarwati, S., Sutasurya, L.A. \& Sumarsono, S.H. (2001), Perubahan profil protein tunas anggota tubuh depan mencit (Mus musculus) akibat perlakuan dengan asam metoksiasetat (MAA). Medika, 27: 363-367.

Ruyani, A., Sudarwati, S., Sutasurya, L.A., Sumarsono, S.H. and Gloe, T. [2003], The laminin binding protein p40 is involved in inducing limb abnormality of mouse fetuses as the effects of methoxyacetic acid treatment. Toxicol. Sci., 75[1], 148-153.

Rosenkran, I., et al., (2000) Mapping and identification C. Mycobacterium tubercolosis proteins by two-dimensional gel electrophoresis, microsequensing and immunodetection, Journal electrophoresis, 2, 935-948

Sarto, C., Frutiger, S., Cappellano, F., Sanchez, J.C., Doro, G., Catanzaro, F., Hughes, G.J., Hochstrasser, D..F. \& Mocarelli, P. (1999), Modified expression of plasma glutathione peroxidase and manganese superoxidase dismutase in human renal cell carcinoma. Electrophoresis, 20: 3458-3466.

Sumaryati, A., Simanjuntak, C.H., Typhoid fever and Salmonellosis in Indonesia, Medical Journal of Indonesia, Proceedin of the third Asia-Pasific Symposium on Typhoid Fever and other Salmonellosis. Denpasar Indonesia, 7, 20-23

Sylvia Y Muliawan, Julius E. Surjawidjaja, 1999. Tinjauan Ulang Peranan Uji Widal sebagai Alat Diagnostik Penyakit Demam Tifoid di Rumah Sakit. Bagian Mikrobiologi, Fakultas Kedokteran Universitas Trisakti. Cermin Dunia Kedokteran No. 124, Jakarta.

Widodo Judarwanto, 2009. OVER DIAGNOSIS DEMAM TIFOID. www.childrenclinic.wordpress.com, 27 Maret 2009, 14.30. 